\title{
Coaching for Improved Teaching - A Virtuous Model for Improving Performance and Increasing Commitment
}

\author{
Cam Caldwell ${ }^{1}$, Ella Carter $^{2} \&$ Larry A. Floyd ${ }^{3}$ \\ ${ }^{1}$ College of Business, Dixie State University, Saint George, UT, USA \\ ${ }^{2}$ College of Business, Bowie State University, Bowie, MD, USA \\ ${ }^{3}$ Georgia State University, Atlanta, GA, USA \\ Correspondence: Ella Carter, College of Business, Bowie State University, Bowie, MD 20715, USA. Tel: \\ 1-301-860-3636, E-email: ecarter@bowiestate.edu
}

Received: November 27, 2015

Accepted: December 18, $2015 \quad$ Online Published: December 19, 2015

doi:10.5430/bmr.v4n4p54

URL: http://dx.doi.org/10.5430/bmr.v4n4p54

\begin{abstract}
In academic institutions around the world, faculty and administrators are searching for new ways to improve teaching effectiveness and prepare students for a more demanding global workplace. Although improving the effectiveness of teaching has long been acknowledged as an important priority, at most academic institutions current performance assessment programs for evaluating faculty effectiveness are often perceived as being limited, ineffective and outmoded. In this paper, we identify key shortcomings of current teaching assessment methods and suggest an improved seven-step coaching model for improving teaching effectiveness. The proposed model also includes ten testable propositions for improving teaching effectiveness.
\end{abstract}

Keywords: Coaching, Assessment, Mentoring, Virtuous teaching, Faculty evaluation

\section{Introduction}

At a 2012 Harvard University conference on improving teaching effectiveness Nobel laureate, Carl E. Wieman, decried the current state of preparing doctoral candidates to teach, the process used to evaluate teaching, and the failure of academic scholars to understand current teaching and best practices about teaching and learning (Berrett, 2012). Although improving the effectiveness of university teaching has been a subject of high importance for more than seventy years, contemporary faculty, and administrators alike are frequently dissatisfied with current teaching evaluation methods (Kane, Kerr, \& Pianta, 2014). Although classroom teaching has historically been the most frequently cited factor for evaluating overall faculty performance in a survey of university deans (Seldin, 1999, p. 7), there continues to be broad disagreement about how to measure teaching effectiveness at the university level and current methods sometimes leave faculty feeling both dissatisfied and mistreated (Elmore, 2008).

The purposes of this paper are to present a coaching model to improve the less effective teaching evaluation systems that are in place at most universities and colleges and to identify why this model is a morally virtuous model for honoring the duties owed by universities. We begin with a brief summary of the literature about current teaching effectiveness and explain why current methods of assessing teaching are ineffective and identify the nature of the obligation of universities and their administrators to develop systems that are morally virtuous. We then 1) introduce and describe a coaching model for improving teaching effectiveness; 2) identify a seven-step model that meshes with research about highly effective performance improvement systems; and 3) present ten testable propositions within our proposed model. We conclude with four major contributions of our paper and address the importance of improving teaching effectiveness.

\section{Literature Review}

\subsection{Understanding Teaching Effectiveness}

Despite the fact that preparing students to "learn and to earn" are primary reasons for creating academic institutions of higher learning (Levitan \& Gallo, 1991), the overwhelming majority of doctoral students who become university professors are rarely trained about how to be effective educators, and those charged with the evaluation responsibilities are as rarely given training about how to assist faculty to improve their teaching or how to conduct a formal teaching evaluation process (Berrett, 2012). Even disagreement about the factors that make up effective 
teaching is common, despite the extensive research that has been written about the topic (Seldin, 2006; Seldin \& Hutchings, 1999). As with other individuals working in other job settings, both faculty who are evaluated and those who assess their teaching are frequently uncomfortable with the assessment process by which teaching is measured (Seldin, Miller, \& Seldin, 2010).

W. Edwards Deming (2000), the man most cited as responsible for quality improvement and Total Quality Management, strongly criticized attempts at performance measurement as misguided processes conducted by poorly trained administrators who failed to understand the factors that determine effective performance. The result of many of those misguided systems, Deming (2000) declared, was to create widespread frustration and dissatisfaction by the victims of such systems. Nobel laureate Wieman's comments at the 2012 Harvard conference suggest that Deming's insights offered many years ago continue to describe the problems of performance appraisal as it relates to assessing teaching effectiveness today (Berrett, 2012).

The primary purposes of teaching assessment programs are to help teachers to improve the quality of their teaching and to enable them become more effective in relating with their students (Griffin, McGaw \& Care, 2011). Although feedback from student surveys has historically been the most common source of information about teaching (Seldin, 1999), there are limits to the effectiveness of student feedback in assessing teaching performance. Marincovich (1998, p. 47), who served as Director of the Stanford University Center for Teaching and Learning, observed that, in her experience, very few teachers have been able to make any significant improvements in their teaching as a result of feedback from their students.

The use of student feedback about teaching effectiveness is a common practice at colleges and universities but can be limited in its validity (Seldin, 1999). DeZure (2000, p. 71) concluded that "student evaluations continue to be valid and reliable to assess many aspects of instruction, but they are not adequate measures of content and its related dimension - pedagogical content knowledge — or ethical standards of practice." Nonetheless, student assessments are used for evaluating teacher effectiveness, even when sample sizes are small or when students are being asked to assess performance that they simply are not qualified to assess (Seldin, 1999).

Similarly, peer evaluations of feedback can be helpful but are also not always valid. Popham (2013) has suggested that faculty peers are an excellent source of teacher assessment with regard to course design, course content, and course goals; the methods and materials used in delivery, evaluation, and grading of student work; and a faculty member's compliance with appropriate ethical standards. Peer bias in assessing teaching nonetheless exists, however, due to 1) disagreement about what constitutes effective teaching; 2) interpersonal relationships between the observer and the faculty member; 3) who selects the observer; 4) reputation of the faculty member being observed; 5) disagreement about what to observe; 6) inconsistency in the assessment process; and 7) lack of training of observing peers (DeZure, 1999, p. 72). DeZure (1999, p. 70) observed that "research on current practice indicates that too often peer classroom observation is neither a reliable nor a valid tool as it is currently used." Sachs and Parsell (2014) observed that peer review, as traditionally established, has historically not been either effective or sustainable as practiced in the modern university.

Peer review can be valuable and helpful, but only if integrated into a teaching and learning process that is comprehensive and supportive, rather than simply informal or judgmental (Buskist, et al., 2014). Buskist and colleagues have suggested a four-part holistic process that incorporates a pre-observation meeting to create high trust, an actual observation, creation of a detailed formal written feedback report, and a post-observation meeting emphasizing the positives identified in the review and offering specific suggestions to help the instructor to become even more effective.

Although some faculty benefit when they utilize a university or college's Center for Teaching (Marincovich (1999, p. 47-49), most faculty choose not to access that potentially valuable resource. Unfortunately, faculties at many universities are given the message that teaching is less important for achieving tenure than publishing in top-tier academic journals (Miller, Taylor, \& Bedeian, 2011). Faculties at some of "the best schools" are still being told by their peers and department heads to spend less time on teaching and to emphasize their scholarly research in top journals - despite the fact that the latest research indicates that much of what is published in academic journals "has become less actionable over time, and so, less useful to our students" (Pearce \& Huang, 2012, p. 247). As a result, teaching at some universities focuses on presenting lectures and asking students to recall that information on multiple choice exams that are easy to grade and that take little time to prepare. Higher order skills that require students to develop their ability to analyze information, to research concepts, and to prepare written reports are deemphasized by faculty who prefer not to spend the time to read and grade more complex learning activities (cf. Paul, Elder, \& Bartell, 1997). 
Faculty and their deans are often not up to date with current advances in learning theory (Berrett, 2012). Most learning at universities and colleges continues to emphasize cognitive learning and follows Bloom's (1956) taxonomy. Although this cognitive approach to knowledge acquisition is an appropriate and necessary part of learning, Wineburg and Schneider (2009, p. 58) note "knowledge possessed does not mean knowledge deployed" and emphasized that great teaching required much more than learning about concepts, definitions, and theories.

Highly regarded scholars note that the application of knowledge is at the heart of both great education (Piper, 1993) and successful organization performance (Pfeffer, 1998). Fink's (2003) Taxonomy of Significant Learning has introduced a model of learning that combines cognitive elements of Bloom's taxonomy with a focus on understanding how one learns, what one cares about, and the importance of the human dimension in the learning process. Fink's (2013) research confirms that traditional cognitive learning methods fail to create meaningful student learning and he advocates creating "significant learning" experiences that appeal to students at the emotional level that enhance their lives, their interactions with others, their commitment to become good citizens in society, and prepare students for the world of work. His model combines key cognitive elements from Bloom with caring about values, integrating the human dimension into the learning process, and helping students to understand how they each learn (Fink, 2003).

Mezirow (2000) emphasized that learning must be transformational, challenging assumptions about previously believed theories and concepts and achieving a threshold of understanding that enables learners to go to a higher level of insight about principles that bear the test of application. Transformational learning acknowledges the insight that Einstein offered in his statement, "The significant problems we face cannot be resolved at the same level that we were at when we created them." Mezirow recognized that students must constantly examine what they believe to define what is and is not reality - meaning that which is frequently believed "conventional wisdom" but not empirically valid (cf. Pfeffer, 1998). Mezirow (2000) suggested that transformational learning allowed students to discover truth by freeing themselves from the conceptual boundaries imposed by assumptions about "accepted theories" that have not been empirically tested.

Tello and colleagues (2013) have recently introduced a new model of transformative learning that integrates key elements of Bloom's taxonomy, Fink's taxonomy, and transformational learning and emphasizes the application of knowledge as the key to learning. Transformative learning incorporates many of the key elements of experiential learning identified by Kolb (1984), but also includes Fink's focus on values and human interaction and Mezirow's openness to defining reality. Incorporating key elements of cognitive, affective, and transformational learning, the transformative learning model engages students at multiple levels and challenges them to integrate theory, facts, values, and their practical application (Tello, et al., 2013). This transformative learning model is consistent with Ramsden's (2003) assessment of the purpose of the learning process.

Ramsden (2003) suggested that the key to effective teaching is to focus on student understanding, or "the way in which students apprehend and discern phenomena related to the subject, rather than what they know about them or how they can manipulate them." Ramsden (2003, p. 4) added that " $(\mathrm{m})$ erely being able to repeat quantities of information on demand is not evidence of a change in understanding - at any level of education. . . (but) is a qualitative change in a person's view of reality."

Elliott and Dweck (2005) challenged prior competency and motivation theories and found that many of the conventional assessment techniques were flawed. They suggested that the focus should be more on the psychological factors as a means of determining how effectively one acquires and uses the new knowledge and skills. Similarly, Gardner (1999) argued that traditional views of intelligence and how it was measured should be replaced by more innovative measures that focus on the concept of multiple intelligences. He suggested that individuals could understand and deploy these multiple intelligences based on the roles they were given but they have a moral responsibility to use those intelligences to create a better world. While neuropsychology of learning theory is noteworthy and provides compelling arguments for using more innovative methods in learning assessment, it is not the focus of this paper.

Rather than focusing on the opinions of students or other subjective observers, known as secondary measures of teaching effectiveness, accrediting bodies identify the importance of evaluating teaching based upon direct measures of teaching effectiveness that are based upon actual samples of student work, including reports, exams, and completed student work products and an emphasis on transformational teaching outcomes (cf. AACSB Accreditation Standard 12). The strength of direct measures of learning is that they provide evidence of what students have learned and what they can actually apply. 


\subsection{Improving Teaching}

Seldin $(1999$, p. 213) has suggested that current teaching evaluation programs fail in two ways: "First, they fail to motivate employees to improve their performance; second, they fail to distinguish between poor, adequate, and good teaching" (Seldin, 1999, 213). To improve teaching effectiveness, Higgerson (1999, p. 196-198) suggested seven factors that she identified as important to creating an improved teaching evaluation system:

1) Faculty understand and accept the organization's mission. A well-conceived mission identifies an organization's focus, goals, and direction and articulates what is valued.

2) Members trust and mutually respect each other. The contribution of faculty members to the mission is understood and appreciated and members feel confident that their colleagues are committed, caring, and competent.

3) Diversity of perspective is valued and acknowledged. Faculty communicate openly and are willing to consider other perspectives without being defensive or resistant to considering other points of view.

4) Faculty members collaborate effectively to achieve shared goals. Well-meaning cooperation involves working together in the pursuit of the mission, goals, and values.

5) All members are informed about key information as valued stakeholders. Faculty are fully engaged participants in the governance process and their input is incorporated in the discussion.

6) Leaders model the commitment to achieving excellence. School and department leaders set the tone by exemplifying the values of the organization and the behaviors expected by its members.

7) Faculty member concerns about issues are responsibly addressed. Those concerns are respected, addressed, and responded to in a professional manner.

Although Higgerson's summary provides a valuable framework for the development of improved teaching, his framework is inconsistently applied (Seldin, 1999). This lack of consistency provides tremendous opportunities to explore innovative models that may address the changing needs of contemporary education institutions. Modern academic institutions are more diverse than ever before and traditional teaching methods are no longer effective with today's tech-savvy students. Newer more stringent accreditation standards are being implemented and increased pressure to meet state and federal educational goals are commonplace. Consequently, these challenges have also changed the roles and responsibilities of faculty and administrators.

\subsection{Moral Obligations in Evaluating Teaching Effectiveness}

In honoring the moral responsibilities associated with improving teaching, university administrators owe duties and obligations 1) to the doctoral students who they train to become future university professors, 2) to faculty who currently endure today's ineffective teaching evaluation systems, 3) to the students who universities and colleges teach, and 4) to a society that demands excellent preparation for tomorrow's workforce. In this section we explain the nature of those moral responsibilities, incorporating the following continuum of moral duty.

We note that Cameron (2003) has suggested that virtuous leaders go above and beyond the responsibilities of leaders to add value, rather than to simply comply with ethical standards (cf. Carroll and Buchholtz, 2014). Accordingly, we present the following moral continuum which includes four distinct ethical positions. As applied to the role of a university leader, that continuum, with a brief description of the moral expectations of a leader at each point, is explained below:

\begin{tabular}{clll}
\multicolumn{1}{c}{ Virtuous } & \multicolumn{1}{c}{ Moral } & Amoral & Immoral \\
\cline { 2 - 3 } $\begin{array}{lll}\text { Optimizes Added Value } \\
\text { and Benefits to Others }\end{array}$ & $\begin{array}{l}\text { Keeps Commitments } \\
\text { and Adds Value }\end{array}$ & $\begin{array}{l}\text { Avoids Violating } \\
\text { Duties but Seeks } \\
\text { Self-Interest First }\end{array}$ & $\begin{array}{l}\text { Disregards Duties } \\
\text { Owed to Others }\end{array}$ \\
& & and Role Obligations
\end{tabular}

The application of this continuum to the teaching evaluation process becomes clearer in context with the table below which identifies these four moral positions as they relate to the implied duties owed to the stakeholders who are affected by the evaluation process for each position. 
Table 1. Teaching-Related Duties for Each Moral Position

\begin{tabular}{|c|c|c|c|c|}
\hline $\begin{array}{l}\text { Stakeholder } \\
\text { Responsibility }\end{array}$ & Virtuous & Moral & Amoral & Immoral \\
\hline $\begin{array}{l}\text { Preparing doctoral } \\
\text { students for future } \\
\text { positions }\end{array}$ & $\begin{array}{l}\text { Provides training } \\
\text { about learning } \\
\text { theory and teaching } \\
\text { effectiveness and } \\
\text { emphasizes need for } \\
\text { them to be great } \\
\text { teachers. }\end{array}$ & $\begin{array}{l}\text { Provides some } \\
\text { training about } \\
\text { teaching } \\
\text { effectiveness. }\end{array}$ & $\begin{array}{l}\text { Does not address } \\
\text { doctoral student } \\
\text { need to become } \\
\text { great teachers. }\end{array}$ & $\begin{array}{l}\text { Instructs doctoral } \\
\text { students to spend as } \\
\text { little time as } \\
\text { possible on teaching } \\
\text { and focus on getting } \\
\text { published in top } \\
\text { journals. }\end{array}$ \\
\hline $\begin{array}{l}\text { Assisting faculty to } \\
\text { understand learning } \\
\text { theory }\end{array}$ & $\begin{array}{l}\text { Provides training } \\
\text { about learning } \\
\text { theory and its } \\
\text { application. } \\
\text { Provides in service } \\
\text { training and }\end{array}$ & $\begin{array}{l}\text { Provides peer } \\
\text { feedback and class } \\
\text { visits and asks peers } \\
\text { to offer teaching } \\
\text { suggestions }\end{array}$ & $\begin{array}{l}\text { Uses some peer and } \\
\text { student feedback to } \\
\text { assist faculty, but } \\
\text { mainly at the } \\
\text { initiative of the } \\
\text { faculty. }\end{array}$ & $\begin{array}{l}\text { Does not provide } \\
\text { feedback about } \\
\text { learning theory and } \\
\text { encourages faculty } \\
\text { to focus on } \\
\text { publications. }\end{array}$ \\
\hline
\end{tabular}

departmental

discussions about

learning theory.

Providing resources to faculty to improve teaching skills

Providing students with cutting-edge knowledge about new concepts in the field and their application

Helping students to develop applied skills

Preparing students for future career successes
Encourages use of an established Center for Teaching and Learning to improve teaching skills and provides a mentor coach for each person.

\section{Conducts department meetings focused on integrating cutting-edge concepts in the classroom and tips about their implementation.}

Requires students to be involved in internships, assistantships, and service learning opportunities to apply skills and emphasizes skill application.

Creates a program that emphasizes assisting students to achieve their greatness and provides multiple opportunities for
May provide a Center for Teaching and Learning and a faculty mentor.

Provides a

mechanism for sharing new ideas but may or may not identify how students can apply those concepts.

Provides some internships and assistantships for top students. Encourages students to engage in service learning.

Provides career development workshops to assist students to be job ready and provides individual counseling as

Responds to faculty Deemphasizes requests for teaching teaching and relies assistance, as requested.

\section{Expects faculty} members to stay current about new concepts as part of their job.

\section{May provide occasional internships and some assistantships. Service learning opportunities are at the initiative of faculty.}

May provide help for individual students. Provides resume review services, on student feedback

to assess faculty with little help offered to improve faculty teaching.

\section{Emphasizes} knowledge delivery to students and traditional cognitive teaching methods. Little application is provided.

Provides assistantships to reduce faculty load, but those internships are mostly clerical tasks of limited value to the students.

Uses grading system as the basis for helping students to qualify for jobs. 


portfolio requested.
development to
assist students to
distinguish
themselves.

\begin{tabular}{|c|c|c|c|c|}
\hline $\begin{array}{l}\text { Providing society with } \\
\text { students who } \\
\text { understand and honor } \\
\text { citizenship obligations }\end{array}$ & $\begin{array}{l}\text { Emphasizes service } \\
\text { to society as a major } \\
\text { value, requires } \\
\text { students to engage } \\
\text { in service learning, } \\
\text { and emphasizes a } \\
\text { campus-wide } \\
\text { academic integrity } \\
\text { program to reinforce } \\
\text { values. }\end{array}$ & $\begin{array}{l}\text { Involves students in } \\
\text { community service } \\
\text { and actively } \\
\text { enforces academic } \\
\text { dishonesty and } \\
\text { plagiarism policies. }\end{array}$ & $\begin{array}{l}\text { May have an } \\
\text { academic dishonesty } \\
\text { program and may } \\
\text { use turnitin.com as a } \\
\text { campus resource. }\end{array}$ & $\begin{array}{l}\text { Gives periodic lip } \\
\text { service to social } \\
\text { responsibility issues } \\
\text { but invests little or } \\
\text { no resources. }\end{array}$ \\
\hline
\end{tabular}

Consistent with the virtuous moral model identified by Cameron (2003), we suggest that university leaders and administrators owe a profound set of duties to maximize the creation of value for all of their stakeholders. This virtuous approach to administrative leadership applies broadly throughout all areas of university administration and has special relevance to creating the best possible means of improving faculty teaching.

\section{Material Studied}

\subsection{Coaching Model for Improved Teaching}

Based on a review of the literature, we present a seven-step model for helping faculty to improve their teaching, briefly explaining each of the seven steps of an administrator, department chair, or senior faculty mentor who serves as the coach of an individual faculty member. We suggest that this model for improving teaching performance is an improvement on the commonly implemented teaching performance evaluation approaches currently employed at most colleges and universities. In addition to presenting this seven-step model, we also include ten related propositions that are testable opportunities to put this model into practice.

1) Demonstrate personal commitment to individual success. Redefining the relationship between the individual being mentored or coached is at the heart of our coaching model. A coaching relationship enables the coach/mentor to be an actual partner, a source of support, and a cheerleader for a faculty member seeking to improve his/her teaching. This highly supportive relationship creates an entirely different social contract and relationship than traditional performance evaluation roles (cf. McGregor, 2005). Rather than the coach/mentor acting as a critic or a judge in the more traditional role, the coach functions as a supporting partner who works with the faculty member to achieve personal excellence - and, ultimately, to successfully qualify for promotion and tenure (Cassidy \& Medsker, 2009). In identifying the roles of leaders and organizations to their employees, DePree (2004, Ch. 1) emphasizes the importance of this same type of relationship, thereby treating employees as partners in a "covenantal" relationship. Our coaching model is centered on the success of the faculty member in improving his/her teaching and defines the coach as a committed participant in the faculty member's success - much as DePree (2004) has outlined.

When a leader/coach is authentic in demonstrating a commitment to an employee or colleague's success, that commitment also translates to a reciprocal higher level of personal commitment and investment on the part of the person being coached (Cheliotes \& Reilly, 2012). Consistent with this information about the coaching relationship, we offer our first proposition.

$\mathrm{P}_{1}$ : Universities who adopt a coach/mentor approach to improving faculty teaching will see faculty respond with higher levels of personal commitment than universities who adopt the more traditional performance evaluation approach.

2) Reinforce teaching to the mission, goals, and values. In focusing the efforts of faculty members on teaching effectiveness, Higgerson (1999) emphasized the importance of tying teaching to the mission, goals, and values of the organization. Understanding the specific student population served by a university, the priority that it places on teaching and research, its expectations about the role that the university plays in the community the values and priorities that frame its declared mission all have an important part in the teaching focus of a university. The coach or mentor has the opportunity to provide context about the university's history and underlying philosophy, and the traditions and culture that serve as the foundation of the university. Buskist and colleagues (2014) emphasized the 
importance of a holistic approach to peer review and coaching that incorporates a multiple set of teaching and learning factors. Understanding the key cultural elements of a university or department enables a faculty member to focus on addressing normative values in addition to the behavioral context and content of teaching (cf. Schein, 2010). Our second proposition addresses the relationship between a university's mission and the teaching effectiveness of faculty.

$\mathrm{P}_{2}$ : University faculty members at universities that incorporate a coaching approach that emphasizes a university's mission, goals, and values into classroom teaching are perceived as better teachers than faculty at universities that do not emphasize incorporating those factors into the teaching of students.

3) Define expected teaching outcomes. "Beginning with the end in mind" is a well-established principle and enables individuals to incorporate clear measuring sticks for goals achieved (Covey, 1990). Defining expectations about student performance; required course content; and teaching outcomes integrated with learning objectives, values, and purposes increases the likelihood that those expectations will be achieved (Robinson \& Gahagan, 2010). Effective coaching includes expectations about the importance of teaching outcomes and preparing students for the application of skills and techniques in their future occupations (Knight, 2007). "Making performance expectations clear and helping faculty understand how individual goals relate" to organization goals are essential in evaluating faculty teaching performance (Higgerson, 1999, p. 200). Our third proposition about coaching and effective teaching follows.

$\mathrm{P}_{3}$ : Faculty members at universities at which their coach/mentor defines clear teaching outcomes are perceived as better teachers than faculty at universities that do not take the time to define clear outcomes in the teaching of students.

4) Incorporate cutting-edge learning theories. Today's learners are more diverse but less prepared than students who have attended colleges and universities in the past, and effective teaching requires the ability to apply cutting-edge learning theories to reach this student population (Ramsden, 1992). To teach effectively, Wieman encouraged faculty to become experts in their knowledge of the practice of teaching, rather than just the content knowledge of their disciplines (Berrett, 2012). Engaging students at the affective level can enable them to have more meaningful learning experiences that can be applied in their lives and careers (Fink, 2003). Coaches and mentors who help faculty to understand how to apply learning theory can assist their mentees to develop teaching strategies that reach today's more diverse student population. Both students and administrators agree that teaching skills that foster long-term engagement with learning tasks and the application of concepts result in more effective student learning (Ramsden, 1992, Ch. 5). Consistent with this coaching element, we offer our fourth proposition.

$\mathrm{P}_{4}$ : Faculty members at universities at which their coach/mentor assists the faculty in applying cutting-edge learning theories in the classroom are perceived as better teachers than faculty at universities that do not provide this coaching.

5) Empower and emphasize personalized teaching. Coaches and mentors that encourage faculty to incorporate into their teaching their individual personalities and personal style empower their mentees, make them full partners in the teaching and learning process, and increase individual teacher engagement and commitment (Bogler \& Somech, 2004; Bogler, 2005). Empowerment is far more than simply assigning responsibility for outcomes but includes personal support, encouragement, and training about outcomes to be achieved (Watts, 2009). Empowering faculty members and allowing them to imbue their teaching with their personal touch enables them to feel personal ownership for their goals and increases their sense of partnership with the organization (Block, 2013). Personal connection between a coach and mentee has been shown to build greater personal commitment, improve performance, and increase personal satisfaction about work to be performed (Boyatzis \& McKee, 2005). We suggest two propositions about the importance of coach or mentor empowerment of faculty.

$\mathrm{P}_{5}$ : Faculty members at universities where their coaches and mentors provide training in achieving learning outcomes and who are supported in those efforts by those coaches and mentors are perceived as better teachers than faculty at universities that do not provide this empowerment and encouragement.

$\mathrm{P}_{6}$ : Faculty members at universities at which their coaches/mentors empower faculty and encourage them to incorporate their own personalities and personal style in the classroom are perceived as more committed and engaged than faculty at universities that do not provide this empowerment and encouragement.

6) Identify individual questions and concerns. Coaches and mentors work most effectively when they listen as well as guide and instruct (Cheliotes \& Reilly, 2012). Listening effectively and responding to individual faculty member needs and concerns strengthens the mentor/mentee relationship and enables a coach to be perceived as emotionally 
connected and supportive (Boyatzis \& McKee, 2005). Each faculty member comes to teaching from a unique background and perspective and requires a personalized response by the coach or mentor (Wise \& Hammack, 2011). Listening to faculty and addressing their specific questions and concerns demonstrates to faculty that they are full partners in the teaching and learning process and increases faculty commitment and performance (Huston \& Weaver, 2008). With regard to the importance of responding to the individual questions and concerns of faculty being coached, we offer our seventh proposition.

$\mathrm{P}_{7}$ : Faculty members at universities at which their coaches/mentors listen to faculty, identify their concerns, and answer their questions are perceived as more effective and committed than faculty at universities that do not provide this empowerment and encouragement.

7) Provide supporting resources and regular feedback. A teaching improvement process that includes specific teaching resources such as faculty access to a Center for Teaching and Learning, periodic departmental meetings about improving teaching effectiveness, and regular feedback about teaching effectiveness has been considered an ideal process for improving teaching effectiveness (Seldin, 1999; Schumann, Peters, \& Olsen, 2013). Incorporating these elements into a coaching and mentoring model demonstrates to faculty that their administrators give teaching high priority (Bosch, Hester, \& MacEntee, 2008). Although Centers for Teaching and Learning have been at some universities for nearly fifty years, their value in helping today's faculty is increasingly relevant in today's complex world (Schumann et al., 2013). Coaching feedback about how faculty can improve their teaching should focus on identifying better ways to achieve teaching outcomes and improving learning, rather than finding fault and placing blame (Deming, 2000). Feedback should be timely, specific, and constructive to be most useful (Gilley, Gilley, \& Kouider, 2010) and is most effective when those who receive that feedback believe that their coaches and mentors are committed to their welfare, growth, and wholeness (Caldwell, 2012). Our eighth proposition addresses the role of coaching in providing resources and its impact upon teaching effectiveness.

$\mathrm{P}_{8}$ : Faculty members at universities at which their coaches/mentors provide regular and timely feedback and resources to help improve teaching are perceived as better teachers than faculty at universities that do not provide this feedback and supporting resources.

Coaching and mentoring systems within the higher education context are increasingly being recognized as contributors to faculty success (Bartalo, 2012). Consistent with research about other integrated processes of human resource management (cf. Pfeffer, 1998), integrating all seven of these steps is more likely to increase faculty member trust, increase commitment, and improve teaching performance than implementing individual elements of this proposed coaching model (cf. Caldwell et al., 2011). Consistent with the research about other human resource management systems, we present our last two propositions.

$\mathrm{P}_{9}$ : Faculty members at universities which implement all seven of these coaching steps are perceived as more committed team members than faculty at universities that do not implement this seven-step coaching model.

$\mathrm{P}_{10}$ : Faculty members at universities which implement all seven of these coaching steps are perceived as better teachers than faculty at universities that do not implement this seven-step coaching model.

Traditional models of faculty evaluation that continue to rely on student feedback and that provide limited or no feedback to faculty about improving their teaching continue to exist at many colleges and universities (Seldin, 1999). These traditional models have been frequently misused in the teaching evaluation processs and in making critical decisions about promotion and tenure (Seldin, $1999 \&$ 2006). The net impact of failing to implement best practices in teacher evaluation is that teaching at many major universities and colleges is delivered at a level that is below the potential that could be offered, students receive a lower quality overall education, other stakeholders are underserved, and society benefits to a lesser extent than is otherwise possible (cf. Berrett, 2012). In today's highly competitive global marketplace, failing to optimize the quality of teaching and education provided by colleges and universities is an underutilization of valuable resources and fails to honor the moral obligations owed by colleges and universities to society (cf. Hosmer, 2010).

\section{Discussion}

In presenting this paper about improving teaching effectiveness through the seven-step model that we have suggested, four significant contributions are made.

1) We join with those scholars who advocate that the current methods of evaluating teaching effectiveness are deficient and call for raising the bar in improving the process used by universities and colleges to improve facultyteaching skills. Despite the fact that thousands of articles and books have been written about improving teaching 
effectiveness many colleges and universities are still using outmoded and ineffective systems that neither prepare faculty to teach nor assist them in improving their teaching methods (Seldin, 1999 \& 2006).

2) We identify a morally virtuous model for university administrators and department chairs to follow in creating added value for all stakeholders impacted by college and university teaching. The coaching model that we present herein incorporates a higher standard of virtuous responsibility that adds value to the education process (cf. Cameron, 2011). Our model also enables university leaders and their faculty to optimize the creation of value for universities, their students, and society and to honor the obligations of virtuous leadership that organizational followers are coming to expect.

3) We provide a seven-step coaching model for improving teaching effectiveness that is congruent with the thinking of other scholars and explain how all seven of these steps can be used by universities to improve teaching. A coaching approach to performance improvement that seeks the welfare, growth, and wholeness of faculty is superior to traditional approaches which do not create a partnership between faculty and their coaches or evaluators (Boyatzis $\&$ McKee, 2005).

4) We offer ten testable propositions for evaluating our seven-step coaching model which can be used by university administrators and department heads, and which may be evaluated by other scholars interested in studying teaching effectiveness. Providing these propositions enables practitioners and scholars with a resource that can be quickly and easily applied and evaluated.

\subsection{Implications}

Our model provides a framework for all the key stakeholders to engage in a meaningful discussion about how teaching effectiveness should be defined and measured. It also challenges institutions to re-examine the full impact of their decisions and whether they are creating environments where all stakeholders can thrive. Some might even argue that faculty, staff and administration have a moral responsibility to look at alternative models that will result in improved teaching, better learning outcomes and a greater sense of commitment..

\subsection{Future Research}

Future research may expand the current model to include additional factors such as teacher efficacy, rank and tenure status. Additional research may also examine faculty reaction to the proposed model and whether institutions that choose to implement the proposed model are actually considered more virtuous than those that do not. Lastly, additional research is also needed to explore the relationship between different management styles and teaching effectiveness and the metrics used in the evaluation process.

\section{Conclusion}

The view that many faculty hold is that administrators and leaders at colleges and universities fail to "practice what they teach" by implementing teaching evaluation programs that neither optimize the quality of teaching provided by their faculties nor the learning opportunities delivered to their students (Caldwell, Karri \& Matula, 2005). In a world where " $(\mathrm{g})$ ood is the enemy of great," today's leaders have a moral obligation to pursue excellence if they wish to compete in an increasingly competitive world economy that demands excellence at all levels (Collins, 2001, p. 1).

In many ways this paper is a challenge to college and university administrators to rethink the moral duties that they owe to their faculty, their universities, the students attending their schools, and society at large. It is a challenge to these academic leaders to honor the higher standard of virtuous leadership advocated by many modern scholars (cf. Cameron, Dutton, \& Quinn, 2003; Cameron \& Spreitzer, 2012; Cameron, 2003). Leaders have an obligation to optimize wealth creation as ethical stewards, and set an example for their students who will one day become the future leaders of a difficult world (Caldwell \& Hansen, 2010).

Although the implementation of the coaching model presented in this paper may require additional time, energy, and financial resources, university administrators have a covenantal duty to honor their obligations to all their stakeholders (Pava, 2003) by investing in improving the effectiveness of their teaching faculties. Contemporary educational institutions demand individuals who are knowledgeable about their discipline, skilled in the application of ideas, and committed to values that honor relationships with others. In order to accomplish these goals, a paradigm shift in the way modern institutions define teaching effectiveness is needed. As universities and colleges focus on innovative ways to optimize teaching effectiveness and prepare their faculties to succeed, they should consider a more virtuous model, one that benefits faculty members, students and society at large. 


\section{References}

Bartalo., D. B. (2012). Closing the Teaching Gap: Coaching for Instructional Leaders. Thousand Oaks, CA: Sage Publishing.

Berrett, D. (2012). Harvard conference seeks to jolt university teaching" The Chronicle of Higher Education. Retrieved Feb. 5, 2012 at http://chronicle.com/article/Harvard-Seeks-to-Jolt/130683/.

Block, P. (2013). Stewardship: Choosing service over self-Interest ( $2^{\text {nd }}$ Ed.). San Francisco, CA:Berrett-Koehler.

Bloom, B. S. (1956). Taxonomy of educational objectives: The classification of educational goals, Handbook 1: cognitive domain. New York: David McKay Company Inc.

Bogler, R. (2005). The power of Empowerment: Mediating the relationship between teachers' participation in decision making and their professional commitment. Journal of School Leadership, 15 (1), 76-98.

Bogler, R. \& Somech, A. (2004). Influence of teacher empowerment on teacher's organizational commitment, professional commitment, and organizational citizenship behavior in schools. Teaching and Teacher Education: An International Journal of Research and Studies, 20(3), 277-289. http://dx.doi.org/10.1016/j.tate.2004.02.003

Bosch, W. C., Hester, J. L., \& MacEntee, V. M. (2008). Beyond lip service: An operational definition of learningcentered college. Innovative Higher Education, 33(2), 83-98. http://dx.doi.org/10.1007/s10755-008-9072-1

Boyatzis, R. E., \& McKee, A. (2005). Resonant Leadership: Renewing Yourself and Connecting with Others through Mindfulness, Hope, and Compassion. Boston, MA: Harvard Business School Publishing.

Buskist, W., Ismail, E. A., \& Groccia, J. E. (2014). A practical model for conducting helpful peer review of teaching in Peer Review of Learning and Teaching in Higher Education: International Perspectives, Sachs, J., and Parsell, M. (Eds.) New York: Springer Publications, pp. 33-52. http://dx.doi.org/10.1007/978-94-007-7639-5_3

Caldwell, C. (2012). Moral Leadership: A Transformative Model for Tomorrow's Leaders. New York: Business Expert Press. http://dx.doi.org/10.4128/9781606492543

Caldwell, C., \& Hansen, M. (2010). Trustworthiness, governance, and wealth creation. Journal of Business Ethics, 97(2), 173-188. http://dx.doi.org/10.1007/s10551-010-0503-4

Caldwell, C., Karri, R., \& Matula, T. (2005). Practicing what we teach - ethical considerations for business schools. Journal of Academic Ethics, 3(1), 1-25. http://dx.doi.org/10.1007/s10805-006-9007-3

Caldwell, C., Truong, D., Linh, P., \& Tuan, A. (2011). Strategic human resource management as ethical stewardship. Journal of Business Ethics, 98(1), 171-182. http://dx.doi.org/10.1007/s10551-010-0541-y

Cameron, K. S. (2003). Ethics, virtuousness, and constant change in N. M Tichy and A. R. McGill (Eds.) The Ethical Challenge: How to Lead with Unyielding Integrity. San Francisco, CA: Jossey-Bass, pp. 186-194.

Cameron, K. S. (2011). Responsible leadership as virtuous leadership. Journal of Business Ethics, 98(1), 25-35. http://dx.doi.org/10.1007/s10551-011-1023-6

Cameron, K. S., Dutton, J. E., \& Quinn, R. E., (Eds.) (2003). Positive Organizational Scholarship: Foundations of a New Discipline. San Francisco, CA: Berrett-Koehler.

Cameron, K. S., \& Spreitzer, G., M. (Eds.) (2013). The Oxford Handbook of Positive Organizational Scholarship. Oxford: Oxford University Press.

Carroll, A. B., \& Buchholtz, A. K. (2014). Business and Society: Ethics, Sustainability, and StakeholderManagement $\left(9^{\text {th }}\right.$ Ed.). Stamford, CT: Cengage.

Cassidy, M. F., \& Medsker, K. L. (2009). Coaching and performance improvement. Performance Improvement Quarterly, 21(2), 3-4. http://dx.doi.org/10.1002/piq.20035

Cheliotes, L. M. G., \& Reilly, M. A. (2010). Coaching Conversations: Transforming Your School One Conversation at a Time. Thousand Oaks, CA: Corwin.

Collins, J. (2001). Good to Great: Why Some Companies Make the Leap . . and Others Don't. New York: Harper Business.

Covey. S. R. (1990). Seven Habits of Highly Effective People: Powerful Lessons in Personal Change. New York, NY: Simon \& Schuster. 
Darling-Hammond, L., Holtzman, D. J., Gatlin, S. J., \& Heilig, J. V. (2005). Does teacher preparation matter? Evidence about teacher certification, Teach for America, and teacher effectiveness. Education Policy Analysis Archives, 13(42). http://dx.doi.org/10.14507/epaa.v13n42.2005

Deming, W. E. (2000). Out of the Crisis. Boston, MA: MIT Press.

DePree, M. (2004). Leadership is an Art. New York, NY: Bantam Doubleday.

Elliot, Andrew J. \& Dweck, Carol S. (eds.) (2005). Handbook of Competence and Motivation. New York, NY: Guilford Press.

Elmore, H. W. (2008). Toward objectivity in faculty evaluation. Academe, 94(3), 38-40.

Fink. L. D. (2003). Creating Significant Learning Experiences: An Integrated Approach for Designing College Courses. San Francisco, CA: Jossey-Bass.

Fink, L. D. (2013). Creating Significant Learning Experiences: An Integrated Approach for Designing College Courses Revised and Updated. San Francisco, CA: Jossey-Bass.

Gardner, H. (1999). Intelligence Reframed: Multiple Intelligences for the $21^{\text {st }}$ Century. New York, NY: Basic Books.

Gilley, A., Gilley, J. W. \& Kouider, E., (2010). Characteristics of managerial coaching. Performance Improvement Quarterly, 23(1), 53-70. http://dx.doi.org/10.1002/piq.20075

Griffin, P., McGaw, B., and Care, E., (Eds), (2014). Assessment and Teaching of $21^{\text {st }}$ Century Skills. New York, NY: Springer.

Hosmer, L. T. (2010). The Ethics of Management. New York, NY: Mcgraw-Hill.

Huston, T., \& Weaver, C. L. (2008). Peer coaching: Professional development for experienced faculty. Innovative Higher Education, 33(1), 5-20. http://dx.doi.org/10.1007/s10755-007-9061-9

Kane, T. J., Kerr, K. A., \& Pianta, R. C. (Eds.) (2014). Designing Teacher Evaluation Systems: New Guidance from the Measures of Effective Teaching Project. San Francisco, CA: Jossey-Bass.

Knight, J. (2010). Five key points to building a coaching program. Journal of Staff Development, 28(1), 26-31.

Kolb, D. A. (1984). Experiential Learning: Experience as a Source of Learning and Development. Englewood Cliffs, NJ: Prentice-Hall.

Levitan, S. A. \& Gallo, F. (1991). Learn to earn: Preparing Americans for work. Occasional Paper. George Washington University Center for Social Policy Studies.

Miller, A. N., Taylor, S. G., \& Bedeian, A. G. (2011). Academic life as management faculty Live It. Career Development International, 16(5), 422-445. http://dx.doi.org/10.1108/13620431111167751

Marincovich, M. (1998). Ending the Disconnect Between the Student Evaluation of Teaching and the Improvement of Teaching: A Faculty Developer's Plea. Palo Alto, CA: National Center for Postsecondary Improvement.

McGregor, D. (2005). The Human Side of Enterprise Annotated Edition. New York, NY: McGraw-Hill.

Mezirow, J., (Ed.). (2000). Learning as Transformation: Critical Perspectives on a Theory in Progress. San Francisco, CA: Jossey-Bass.

Paul, R, Elder, L, \& Bartell, T. (1997). California Teacher Preparation for Instruction in Critical Thinking: Research Findings and Policy Recommendations. Sonoma, CA: Foundation for Critical Thinking.

Pava, M., (2003). Leading with Meaning: Using Covenantal Leadership to Build a Better Organization. New York, NY: Palgrave Macmillan.

Pearce, J. L., \& Huang, L. (2012). The decreasing value of our research to management education. Academy of Management Learning \& Education, 11(2), 247-262. http://dx.doi.org/10.5465/amle.2011.0554

Pfeffer, J. (1998). The Human Equation: Building Profits by Putting People First. Boston, MA: Harvard Business School Press.

Piper, T. R. (1993). Rediscovery of purpose: The genesis of the leadership, ethics, and corporate responsibility initiative in T. R. Piper, M. C. Gentile, \& S. D. Parks (Eds.) Can Ethics be Taught? Perspectives, Challenges, and Approaches at Harvard Business School, Boston, MA: Harvard Business School Press, 1-12.

Popham, W. J. (2013). Classroom Assessment: What Teachers Need to Know ( th $^{\text {th }}$ Edition). New York, NY: Pearson. 
Robinson, C., \& Gahagan, J. (2010). Coaching students to academic success and engagement on campus." About Campus, 15(4), 26-29. http://dx.doi.org/10.1002/abc.20032

Sachs, J. \& Parsell, M. (2014). Introduction: The place of peer review in learning and teaching in Peer Review of Learning and Teaching in Higher Education: International Perspectives, Sachs, J., and Parsell, M. (Eds.) New York: Springer Publications, pp. 1-12. http://dx.doi.org/10.1007/978-94-007-7639-5_1

Schein, E. A. (2010). Organizational Culture and Leadership. San Francisco, CA: John Wiley \& Sons.

Schumann, D. W.,, J., \& Olsen, T. (2013). Co-creating value in teaching and learning centers. New Directions for Teaching and Learning, 133, 21-32. http://dx.doi.org/10.1002/t1.20043

Seldin, P. (2006). Evaluating Faculty Performance: A Practical Guide to Assessing Teaching, Research, and Service. San Francisco, CA: Jossey-Bass.

Seldin, P., \& Hutchings, P. (1999). Changing Practices in Evaluating Teaching: A Practical Guide to Improved Faculty Performance and Promotion/Tenure Decisions. San Francisco, CA: Jossey-Bass.

Seldin, P., Miller, J. E., \& Seldin, C. A. (Eds.), (2010). The Teaching Portfolio: A Practical Guide to Improved Performance and Promotion/Tenure Decisions. San Francisco, CA: Jossey-Bass.

Tello, G., Swanson, D., Floyd, L., \& Caldwell, C. (2013). Transformative learning: A new model for business ethics education.” Journal of Multidisciplinary Research, 5(1), 105-120.

Vogt, F. \& Rogalla, M. (2009). Developing adaptive teaching competency through coaching. Teaching and Teacher Education: An International Journal of Research and Studies, 25(8), 1051-1060. http://dx.doi.org/10.1016/j.tate.2009.04.002

Watts, D. M. (2009). Enabling School Structure, Mindfulness, and Teacher Empowerment: Test of a Theory. The University of Alabama.

Wineburg, S. \& Schneider, J. (2009). Was Bloom's taxonomy pointed in the wrong direction? Phi Delta Kappan, 91(4), 56-61. http://dx.doi.org/10.1177/003172171009100412

Wise, D. \& Hammack, M., (2011). Leadership coaching: Coaching competencies and best practices. Journal of School Leadership, 21(3), 449-477. 